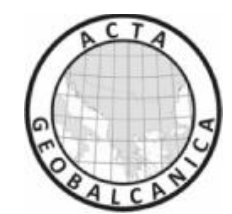

\title{
DAMAGE CAUSED BY NATURAL DISASTERS IN SLOVENIA BETWEEN 1991 AND 2008
}

\author{
Ass. Prof. Dr. Matija Zorn ${ }^{1}$ \\ Mauro Hrvatin ${ }^{1}$ \\ ${ }^{1}$ Research Centre of the Slovenian Academy of Sciences and Arts, \\ Anton Melik Geographical Institute, Slovenia. \\ Corresponding author: matija.zorn@zrc-sazu.si
}

\begin{abstract}
This paper presents an analysis of data on damage caused by natural disasters in Slovenia. The data were systematically collected by the Statistical Office of the Republic of Slovenia from 1991 to 2008 for fourteen categories of disasters: earthquakes, floods, fires, drought, windstorms, hail, frost, glaze, landslides and avalanches, epidemics, epizootics, damage caused by various pests and diseases, ecological disasters, and other natural disasters. Data by statistical regions (NUTS 3) are available for 1992 to 2008, and data by municipalities (LAU 2) and administrative units (LAU 1) are available for 1992 to 2005. Analysis of the data shows that from 1991 to 2008 direct damage caused by natural disasters amounted to an average of $0.48 \%$ of annual GDP, or an average of $€ 45$ per capita a year.
\end{abstract}

Keywords: natural disasters, damage, Slovenia

\section{INTRODUCTION}

Natural disasters and damage are closely connected to one another because what happens in the natural environment is merely considered a normal natural process - if no harm is caused to society (damage or victims). In the event of a natural disaster, damage is at the centre of the public discourse in addition to protection and rescue [1].

Direct damage occurs during the disaster itself (e.g., damaged buildings and infrastructure, destroyed crops), whereas indirect damage is caused in other areas and can be considerably greater than direct damage (e.g., lost income due to interrupted industrial production, agriculture, commerce, and power supply). Some authors [2] also refer to secondary damage, which is financial in nature and connected with lost budget funds, changed interest rates, and debt.

The damage caused by natural disasters is increasing around the globe, and not because of their potentially higher frequency, but the increased vulnerability of society. Greater vulnerability of society is connected with the rapid increase in population, settlement of hazardous locations that were empty until only recently, more frequent increases in population density, and a larger share of urban population. Greater vulnerability is also influenced by increasing property and real-estate prices, a more diverse and modern (expensive) infrastructure, and especially human alienation from the natural 
environment. There is also a resulting lack of knowledge of natural processes, and denying or even underestimating them [3].

In the 1950s, the average cost of damage caused by natural disasters was globally around $\$ 3.9$ billion per year [4]. This was followed by a jump in the damage recorded, finally amounting to an average of nearly $\$ 120$ billion a year in the last twenty years.

When citing the global data on damage, one must proceed with caution because in the past a great deal of damage caused by natural disasters was not recorded and thus the total damage caused has been underestimated [2]. On the other hand, there is considerable exaggeration in reporting the cost of damage, especially in developing countries, which seek to secure more international aid this way [5]. In addition, collecting data on damage is not systematic and also not methodologically uniform; data on direct damage predominate [2] and Slovenia is no exception.

The data on the damage caused by natural disasters in Slovenia were systematically collected by the Statistical Office of the Republic of Slovenia [6]. The data collected cover the period from 1991 to 2008 and can be divided into fourteen categories of disasters: earthquakes, floods, fires, drought, windstorms, hail, frost, glaze, landslides and avalanches, epidemics, epizootics, damage caused by various pests and diseases, ecological disasters, and other natural disasters. The first nine are discussed in detail below. The data are examined at the level of statistical regions (i.e., NUTS 3) while taking into account that they are incomplete because it is highly likely that not all the damage caused by natural disasters was forwarded to the Statistical Office [7]. The office stopped collecting these data in 2009.

\section{DAMAGE AT THE NATIONAL LEVEL}

The literature on the damage caused by natural disasters in Slovenia usually cites amounts from 0.6 to $3 \%$ of the annual GDP, unless a major disaster occurs in a given year. In the event of major natural disasters, this percentage is higher; for example, the damage caused by the 1976 earthquakes in the Soča Valley (north-western Slovenia) was estimated at approximately 7\% of GDP and the damage caused by the 1990 floods in the Savinja Basin (northern and north-eastern Slovenia) was said to even exceed 20\% of GDP. These numbers are fairly high and include both direct and indirect damage [3, 7].

According to Statistical Office data, the direct damage caused by natural disasters during the period studied (1991-2008) amounted to an average of $0.48 \%$ of the annual GDP or an average of $€ 45$ per capita a year.

Two powerful earthquakes struck Slovenia during the period discussed and caused substantial damage: one in 1998 and one in 2004. Because they both occurred in the Upper Soča Valley (northwest Slovenia), it is understandable that the damage was the greatest in the Goriška Statistical Region. These earthquakes caused 18\% (in 1998) and $13 \%$ (in 2004) of the total damage caused by natural disasters in Slovenia as a whole.

"High water appears every year in Slovenia and is common. It can appear in any season, but most often in the fall. ... Over the past century, not even a decade has been without major floods. They have appeared across all of Slovenia" [8]. This has also been the case in the last twenty-five years, when floods have caused an average of $15 \%$ of the 
total damage due to natural disasters in the country. The following years have stood out in this regard: 1991 (38\% of the total damage caused by natural disasters), 1994 (31.3\%), 1995 (18.1\%), 1998 (51.9\%), 1999 (12.1\%), 2004 (15.2\%), and 2007 (64.8\%).

Fires caused just over $5 \%$ of the total damage during the period studied. They caused substantial damage in Slovenia in 2002 (18.1\%) and 2004 (24.5\%). One should bear in mind that the data on fires include all fires in the natural environment regardless of how they were started, and not only fires that started naturally.

Drought caused the most direct damage in Slovenia (just over 27\%; Figure 1). The following years have stood out in this regard: $1992(81.2 \%), 1993(89.5 \%), 1997$ (16.3\%), 2000 (70.2\%), 2001 (56.7\%), 2003 (83.3\%), 2006 (60.4\%), and 2007 (13.4\%).

Windstorms caused an average of $14 \%$ of the total damage in the country. The following years have stood out in this regard: 1991 (35\%), 1994 (26.1\%), 1995 (37.5\%), 1997 (13.8\%), 1999 (26.6\%), 2002 (15.6\%), 2005 (31.4\%), 2007 (12.7\%), and 2008 $(19.6 \%)$.

Hail was in second place in terms of the damage caused (just under 18\%; Figure 1). The following years have stood out in this regard: 1994 (16.5\%), 1995 (16.3\%), 1996 (12.4\%), 1997 (17.4\%), 1999 (11.6\%), 2001 (12\%), 2002 (20.6\%), 2004 (38.7\%), 2005 (55.6\%), 2006 (23\%), and $2008(75.2 \%)$.

Frost and glaze were less problematic (they caused just under 5\% and just above $2 \%$ of the total damage, respectively). Frost caused substantial damage in 1991 (14\%), 1997 (27\%), and 2001 (23.6\%), and glaze was a problem especially in 1996 (37.6\%). Glaze also caused enormous damage in early 2014.

Unfortunately, the Statistical Office collected data on the damage caused by landslides and avalanches together. Considering that avalanches did not cause substantial damage during this period, it can be concluded that the majority of damage was caused by landslides. According to these data, landslides and avalanches caused $9 \%$ of overall damage due to natural disasters. The following years have stood out in this regard: 1991 (11.1\%), 1994 (10.2\%), 1995 (16\%), 1996 (22.4\%), 1998 (14.1\%), 1999 (32.1\%), and $2002(17.8 \%)$.

The diagram (Figure 2) showing the direct damage caused by natural disasters in Slovenia between 1991 and 2008 reveals that the cost and structure of damage differed significantly between years. There were years in which Slovenia was not struck by any major natural disaster and the damage caused barely reached $€ 20$ million (e.g., 1991 and 2002). However, years in which at least one disaster stood out were more frequent; in these cases, the cost of the damage caused was between $€ 20$ and $€ 80$ million. These are the cases in which Slovenia is affected by moderate-intensity natural disasters that are limited to individual regions, most frequently hail, windstorms, and frost. The greatest damage, the cost of which usually amounts to $€ 80$ to $€ 160$ million, is caused by disasters that affect the entire country or a large part of it. In the period studied, the greatest damage was caused by drought (in 1992, 1993, 2000, and 2003) and floods (in 1998 and 2007). 


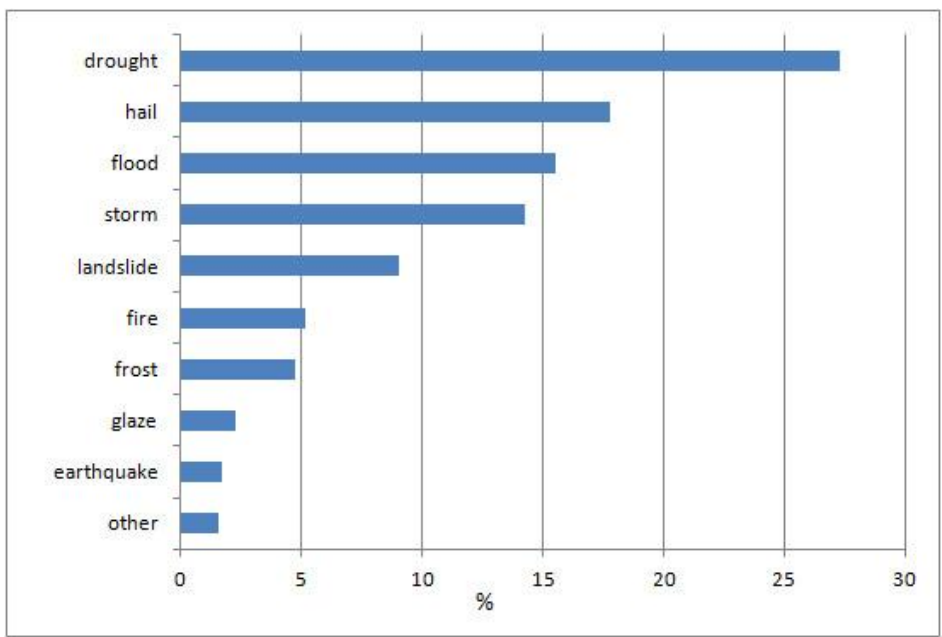

Figure 1: Share of direct damage caused by individual natural disasters in Slovenia from 1991 to 2008.

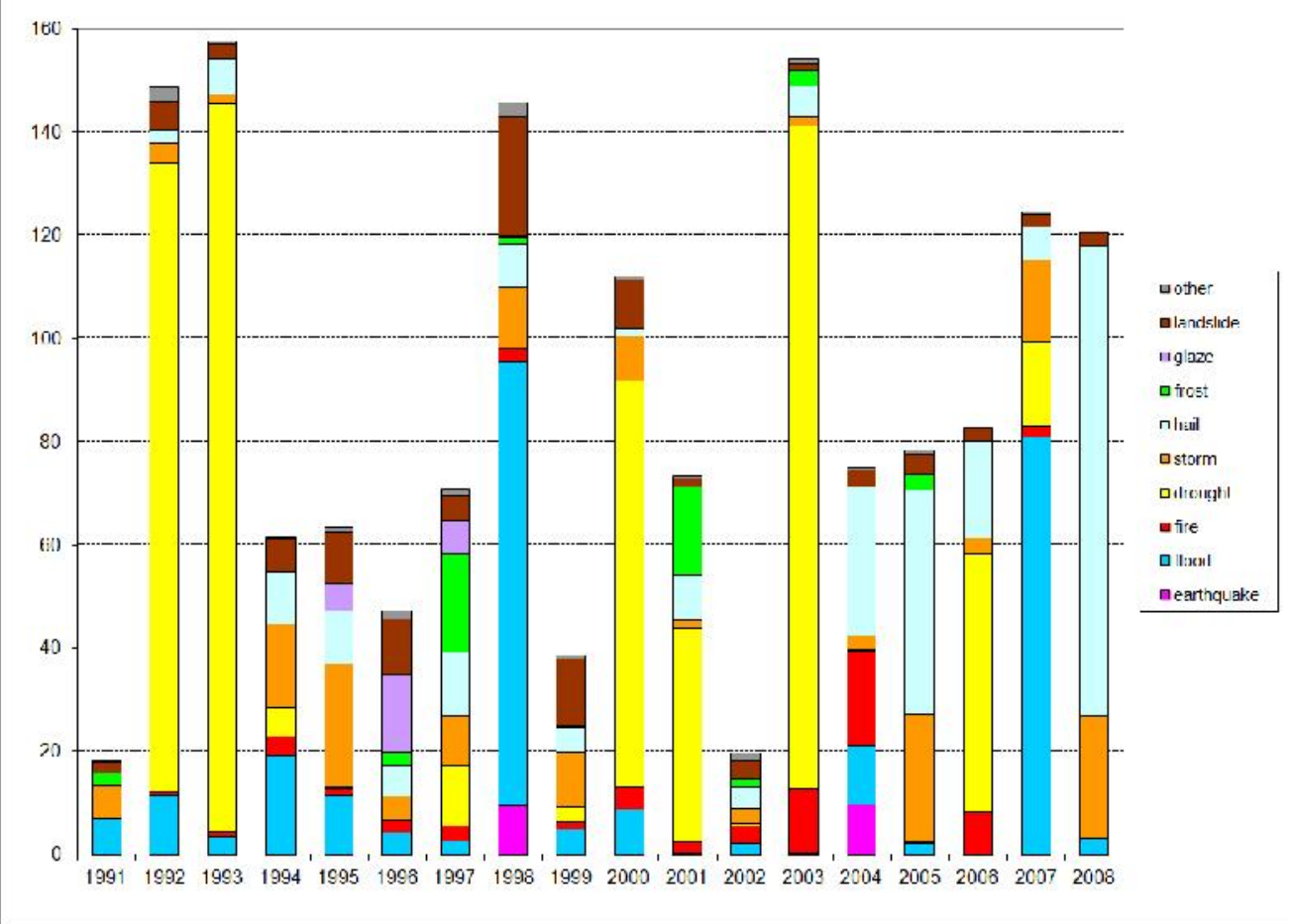

Figure 2: Direct damage caused by natural disasters in Slovenia from 1991 to 2008 in $€$ million by disaster.

Based on the variation coefficient of the cost of damage by natural disaster (Table 1), it was determined which natural disasters incur relatively similar damage costs through the years and are thus more predictable, and which occur sporadically and thus cause unpleasant surprises. From 1991 to 2008, the most predictable damage was caused by windstorms, landslides and avalanches because they occurred every year, but such damage was never extremely high. Somewhat less predictable was the damage caused by fires, hail, and drought. In general, these disasters occur every year, but their intensity can vary a lot. They can cause tens of million euros of damage in individual years. Even less predictable are floods and frost, which can be less significant and cause little damage for several years in a row, but severely strike extensive areas in a specific 
year. Glaze and earthquakes vary the most. Glaze and strong earthquakes occur fairly rarely, but when they do their impact is great and requires extended recovery.

Table 1: Coefficients of variation for the cost of damage by selected natural disaster in Slovenia in the period studied.

\begin{tabular}{lrrr}
\hline & $\begin{array}{c}\text { Standard } \\
\text { deviation }\end{array}$ & Arithmetic mean & $\begin{array}{r}\text { Coefficient of } \\
\text { variation }\end{array}$ \\
\hline Earthquakes & $3,112.1$ & $1,069.1$ & 2.9108 \\
\hline Glaze & $3,863.2$ & $1,517.6$ & 2.5457 \\
\hline Frost & $5,731.0$ & $2,802.5$ & 2.0449 \\
\hline Floods & $25,618.7$ & $14,446.2$ & 1.7734 \\
\hline Drought & $49,770.9$ & $33,285.8$ & 1.4953 \\
\hline Hail & $21,726.9$ & $15,006.0$ & 1.4479 \\
\hline Fires & $4,765.9$ & $3,775.1$ & 1.2624 \\
\hline Landslides and & $5,539.4$ & $6,038.4$ & 0.9174 \\
avalanches & & & \\
\hline Windstorms & $8,075.1$ & $9,630.8$ & 0.8385 \\
\hline Other & 772.4 & 944.4 & 0.8178 \\
\hline
\end{tabular}

\section{DAMAGE AT THE LEVEL OF STATISTICAL REGIONS (NUTS 3)}

The structure of damage caused by natural disasters varies significantly between individual statistical regions. Drought and floods usually predominate, whereas the structure and share of other natural disasters vary greatly. Nonetheless, some statistical regions are fairly similar in terms of damage structure. In order to identify such groups, the statistical regions were classified into clusters using a hierarchical clustering method. This is a popular method because the user does not have to specify the final number of clusters in advance and at the same time can present the results of agglomerative clustering very clearly in a dendrogram [9].

Cluster analysis includes the following steps [9]:

1. Selecting the objects (cases);

2. Defining the set of variables;

3. Calculating the similarity between objects;

4. Using a suitable clustering method;

5. Evaluating the solution obtained.

The clustering objects in this case were the Slovenian statistical regions and the set of variables used comprised the percentages of individual natural disasters as part of the total damage caused. The following natural disasters were taken into account: earthquakes, floods, fires, drought, windstorms, hail, frost, glaze, landslides and avalanches (together), and others. Because all of the variables used were of the same type, they did not have to be standardized.

The similarity between objects was calculated based on the Euclidean distances, in which the differences between variables are squared before they are added up.

The best clustering results were obtained by using Ward's method, which is generally considered very effective. The only drawback that this method is commonly criticized for is that the clusters formed are too small. 
The agglomerative clustering of objects was illustrated with a dendrogram (Figure 3). The height of each node, also referred to as the linkage distance, is proportional to the value of the integroup dissimilarity [9].

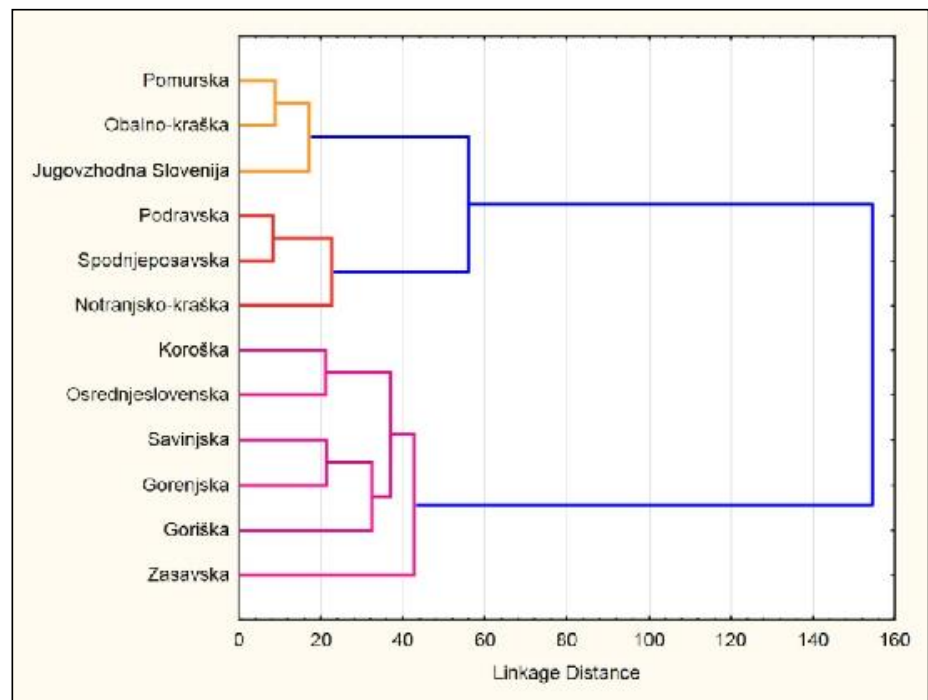

Figure 3: Dendrogram showing the clustering of statistical regions in terms of damage structure.

Based on the hierarchical clustering, three groups with a similar structure of damage caused by natural disasters were identified. The predominant natural disaster in the first group is drought (yellow group in Figure 3; Figure 4), the second group includes a combination of drought and hail (red group in Figure 3; Figure 5), and the third group (pink group in Figure 3; Figure 6) combines the statistical regions in which other natural disasters in addition to drought and hail are important. These are mainly floods and windstorms, and exceptionally also earthquakes, avalanches and landslides.

The first group (Figure 4) includes the Pomurska, Obalno-kraška, and Jugovzhodna Slovenija statistical regions. By far, the most important natural disaster in this group is drought (60-68\%), followed by hail (13-19\%). No other natural disaster accounts for a share of $10 \%$ in any of the statistical regions in this group.

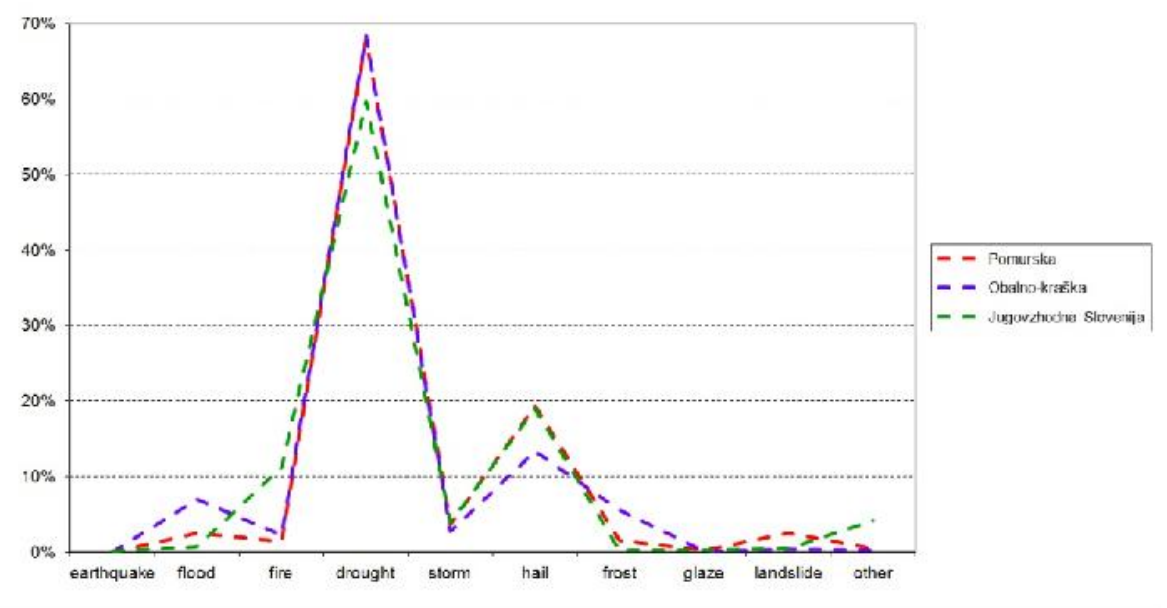

Figure 4: Distribution of damage caused by natural disasters in the first group.

The second group (Figure 5) includes the Podravska, Spodnjeposavska, and Notranjskokraška statistical regions. This group is also dominated by drought (40-47\%), but 
significant damage is also caused by hail (17-32\%). The only other ten-percent share in this group is reached by floods in the Notranjsko-kraška Statistical Region.

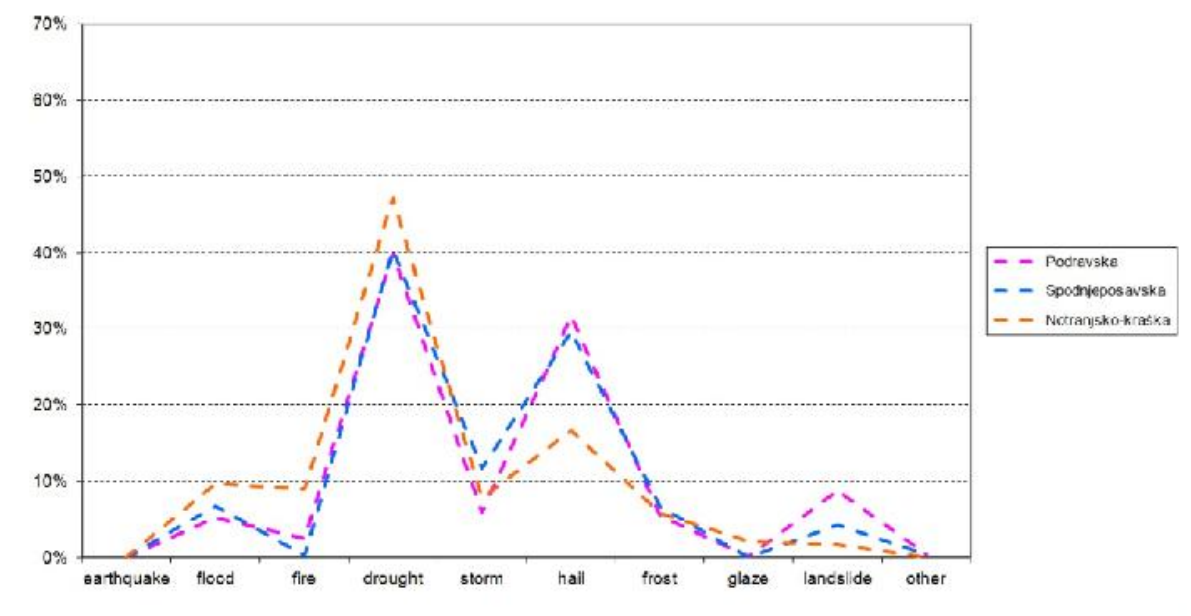

Figure 5: Distribution of damage caused by natural disasters in the second group.

The third group (Figure 6) is both the largest and the most heterogeneous, and includes the Koroška, Osrednjeslovenska, Savinjska, Gorenjska, Goriška, and Zasavska statistical regions. The most important natural disaster in this group is floods (14-41\% of overall damage). Large shares of the total damage can also be ascribed to drought (5$36 \%$ ), windstorms (6-28\%), and landslides and avalanches (6-24\%). In the Goriška Statistical Region, $23 \%$ of the total damage was caused by multiple earthquakes.

In addition to the structure of damage in terms of individual natural disasters, the distribution of the total damage caused by natural disasters was also examined (Figures 7-9).

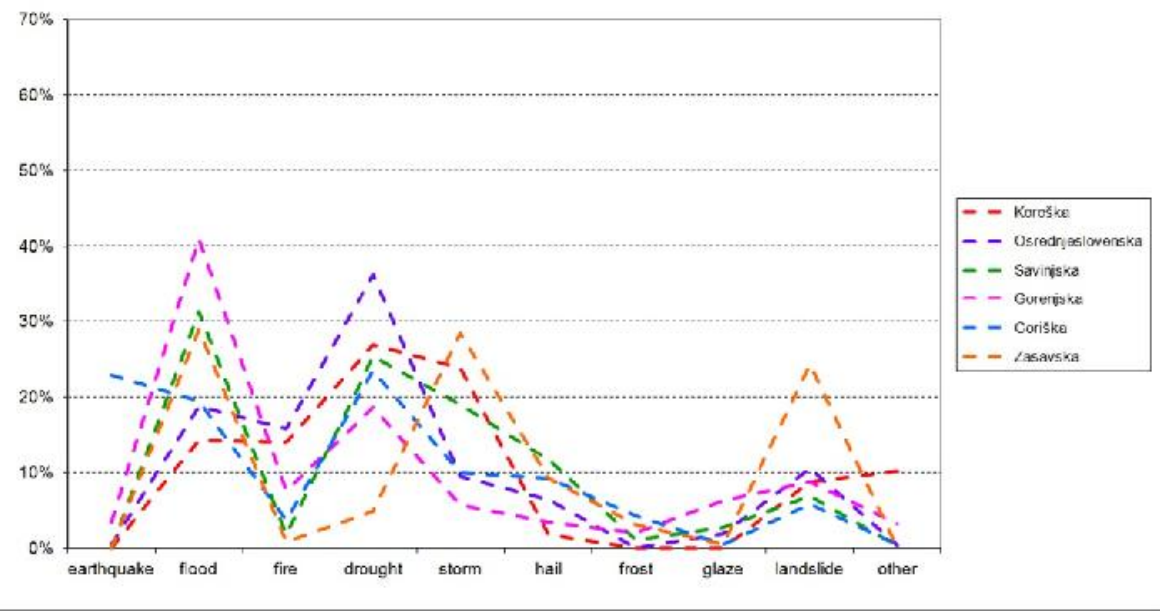

Figure 6: Distribution of damage caused by natural disasters in the third group. 


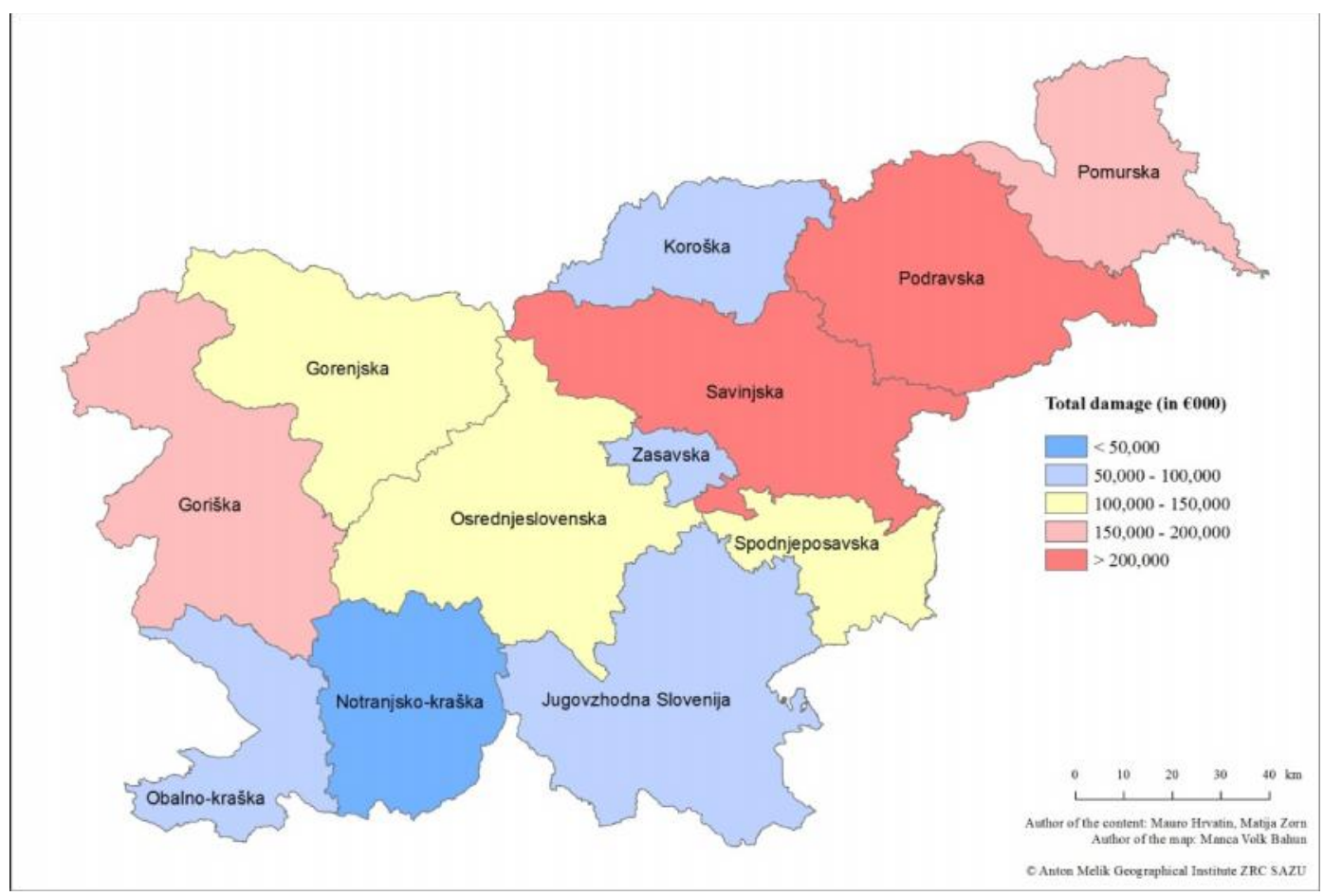

Figure 7: Total damage caused by natural disasters by statistical region from 1992 to 2008.

Figure 7 shows the total damage caused by natural disasters by statistical region from 1992 to 2008. Even at first glance, it is evident that the statistical regions in northeast Slovenia (the Savinjska, Podravska, and Pomurska statistical regions) recorded the greatest damage. In western Slovenia, only the Goriška Statistical Region is included in the top class. Considering that drought was the most frequent natural disaster in the period studied (Figure 1), this kind of distribution across the most important agricultural statistical regions was expected. Moderate damage was recorded in central Slovenia (the Gorenjska, Osrednjeslovenska, and Spodnjeposavska statistical regions), and the smallest damage was recorded in the Dinaric and certain Alpine areas, where arable farming is only a secondary activity.

Figure 8 shows the total damage caused by natural disasters per $\mathrm{km}^{2}$ of individual statistical regions from 1992 to 2008. This map, too (perhaps even more than the previous one), highlights the damage caused by drought in the most important arable farming areas in Slovenia. In every statistical region of eastern Slovenia, this damage exceeded $€ 130,000 / \mathrm{km}^{2}$, and a large part of western and central Slovenia recorded a damage below $€ 60,000 / \mathrm{km}^{2}$. The lowest damage, barely $€ 16,000 / \mathrm{km}^{2}$, was recorded in the predominantly wooded and underpopulated Notranjsko-kraška Statistical Region. 


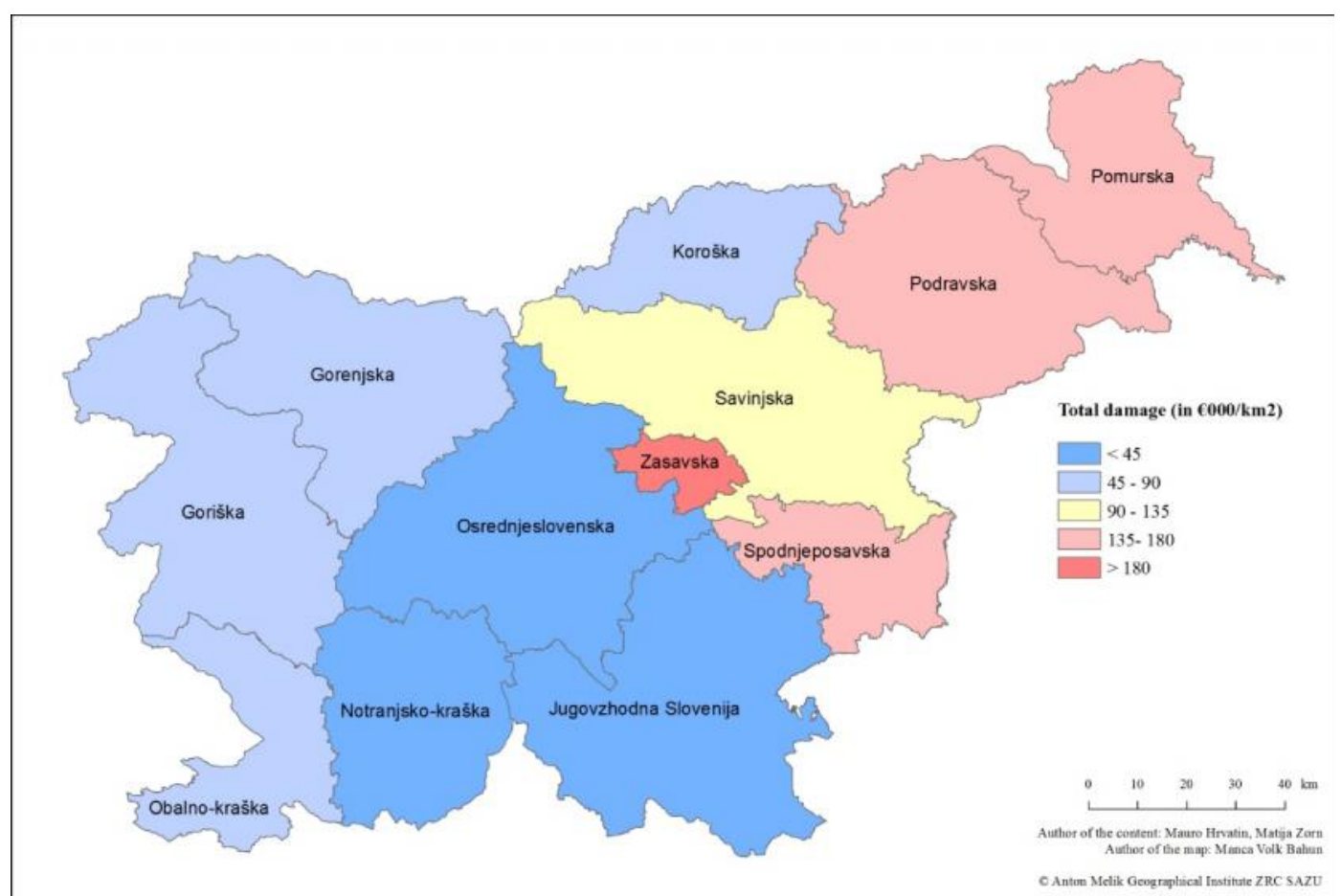

Figure 8: Total damage caused by natural disasters per $\mathrm{km}^{2}$ of statistical region, 1992-2008.

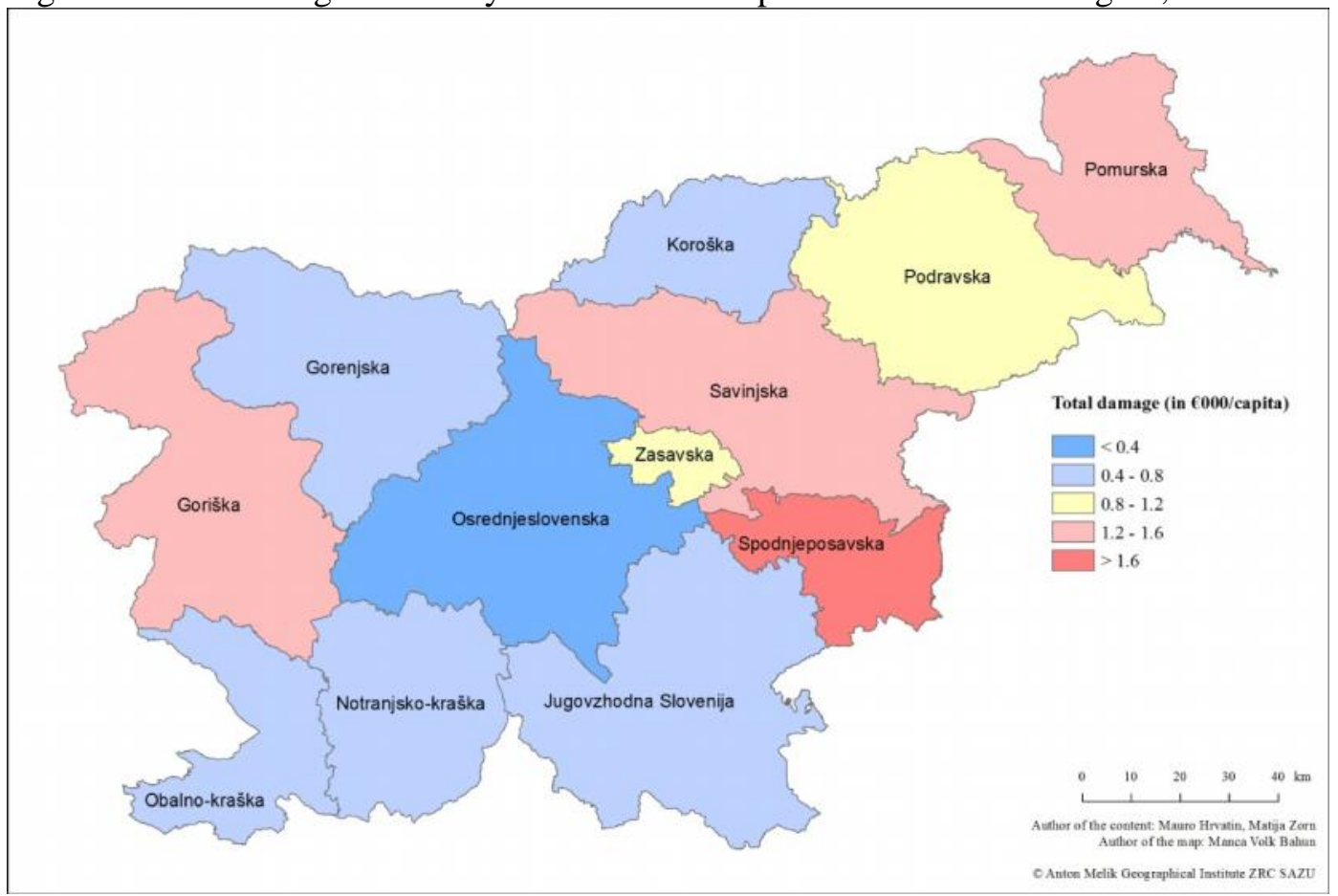

Figure 9: Total damage caused by natural disasters per capita by statistical region, 1992-2008.

Figure 9 shows the total damage caused by natural disasters per capita in individual statistical regions between 1992 and 2008. Also in this case, the highest classes with damage exceeding $€ 1,000$ per capita include the statistical regions in northeast and eastern Slovenia (the Pomurska, Podravska, Savinjska, Zasavska, and Spodnjeposavska statistical regions). Another statistical region highlighted on the map is the sparsely populated Goriška Statistical Region, which was affected the most by multiple earthquakes, and not drought. Due to the moderate damage suffered and fairly high 
population density, the Osrednjeslovenska Statistical Region is in the lowest class, with damage of $€ 224$ per capita.

\section{CONCLUSION}

In many regions natural disasters are a geographical constant [10]. Because they are natural processes, it can be claimed that "they have accompanied mankind from time immemorial, and will continue to present a constant threat to individuals and society as a whole in the future despite the rapid development of science and technology" [11]. Even though natural disasters are not unexpected, people mainly react to them only after they have already occurred. The damage is correspondingly great.

Globally, natural disasters have claimed an average of more than 64,000 lives a year over the past two decades and caused approximately $\$ 120$ billion of damage a year. In Slovenia, damage due to natural disasters amounted to an average of $0.48 \%$ of annual GDP during the past twenty-five years.

In the modern world, where capital plays the predominant role, information on damage is key in promoting prevention. According to an estimate by the World Bank and the U.S. Geological Survey, the global economic damage caused by natural disasters during the 1990 s could have been $\$ 280$ billion lower if $\$ 40$ billion had been invested in advance in natural disaster prevention and preparedness [2]. For example, calculations for Slovenia show that landslide susceptibility maps could be produced for all of Slovenia using funds in the amount just under $5 \%$ of the damage that landslides have caused in the past twenty-five years [12].

From 1991 to 2008, the Statistical Office of the Republic of Slovenia collected data on the damage caused by natural disasters. These data form the basis for this article, which presents the damage caused at the level of statistical regions (NUTS 3). In terms of the total damage caused, the regions in northeast and eastern Slovenia stand out the most, which is primarily connected with the damage in agriculture caused by drought. In 2009, the statistical office stopped collecting these data. Due to a lack of appropriate data, a lack of suitable analyses can be expected in the future and, without these analyses, it will be difficult to take appropriate measures. The costs of collecting and analysing data are minute compared to the damage that natural disasters cause every year. Therefore, collecting and analysing data on the damage caused by natural disasters is imperative. 


\section{REFERENCES}

[1] Komac, B. \& Zorn, M. Geografija poplav v Sloveniji septembra 2010, Neodgovorna odgovornost, Naravne nesreče, vol. 2, Slovenia, pp. 59-80, 2011.

[2] Guha-Sapir, D., Hargitt, D. \& Hoyois, P. Thirty years of natural disasters 19742003: The numbers. Belgium, 2004.

[3] Zorn, M. \& Komac, B. Damage caused by natural disasters in Slovenia and globally between 1995 and 2010, Acta geographica Slovenica, Slovenia, vol 51(1), pp. 7-41, 2011.

[4] Riebeek, H. The rising costs of natural hazards, NASA Earth Observatory (March 28 2005). URL: http://earthobservatory.nasa.gov/Features/RisingCost/printall.php.

[5] Raschky, P. A. Institutions and the losses from natural disasters, Natural Hazards and Earth System Sciences, Germany, vol. 8, pp. 627-634, 2008.

[6] Ocenjena škoda, ki so jo povzročile elementarne nesreče, Slovenia, 2010. URL: http://www.stat.si/pxweb/Database/Okolje/27_okolje/05_Nesrece/27089_ocenjena_sko da/27089_ocenjena_skoda.asp.

[7] Zorn, M. \& Hrvatin, M. Škoda zaradi naravnih nesreč v Sloveniji, (Ne)prilagojeni, Naravne nesreče, Slovenia, vol. 3, 187-206, 2014.

[8] Polajnar, J. Visoke vode, Nesreče in varstvo pred njimi, Slovenia, pp. 246-251, 2002.

[9] Ferligoj, A. Razvrščanje v skupine, Metodološki zvezki, Slovenia, vol. 4, 1989.

[10] Komac, B. Social memory and geographical memory of natural disasters, Acta geographica Slovenica, Slovenia, vol. 49(1), pp. 199-226, 2009.

[11] Natek, K. Fizična geografija in preučevanje ogroženosti zaradi naravnih in drugih nesreč, Dela, Slovenia, vol. 20, pp. 133-146, 2003.

[12] Zorn, M., Komac, B. \& Kumelj, Š. Mass movement susceptibility maps in Slovenia: The current state, Geografski vestnik, Slovenia, vol. 84(1), pp. 99-112, 2012. 